\title{
EXPLORING THE INTEGRATIONS OF MALL INTO EFL LEARNING FOR INDONESIAN SECONDARY SCHOOLS
}

\author{
${ }^{1}$ Bramy Biantoro* \\ ${ }^{1}$ Universitas Muhammadiyah Malang, Indonesia \\ *Corresponding Author: bramybian@gmail.com
}

\begin{abstract}
The use of mobile technology for education is on the rise across the world, especially in Indonesia. However, there are concerns in making such an educational revolution as mobile technology may introduce negative side effects to the Indonesian students. Also, only a few studies have discussed the use of mobile technology in Indonesian secondary schools. Those circumstances potentially make many stakeholders doubt the proper implementation of mobile technology-based learning and the possible challenges, especially in English as a foreign language (EFL) classroom. Thus, this paper is aimed to provide theoretical insights into the implementation of mobile-assisted language learning (MALL) for secondary school students in EFL classrooms. A secondary source analysis through systematic review was employed to generate the findings, focusing on MALL and EFL primary research and government documents related to education in secondary schools. Based on the findings, this paper offers an improved teaching and learning approach based on collaborative learning and task-based language teaching (TBLT) to facilitate better implementation and integration of MALL in EFL classrooms. In addition, the findings also show possible challenges during the implementation of MALL in Indonesia for future considerations, such as the technology readiness of EFL stakeholders and teachers' pedagogical issues related to mobile learning. Lastly, this paper is expected to raise awareness of MALL opportunities and open more paths for more primary research regarding the implementations of MALL in Indonesian EFL classrooms.
\end{abstract}

Keywords: EFL Learning; Instructional Design; Mobile-Assisted Language Learning; Secondary Schools; Task-Based Language Teaching

\begin{abstract}
ABSTRAK
Penggunaan teknologi mobile di dunia pendidikan tengah mengalami peningkatan di seluruh dunia, termasuk di Indonesia. Sayangnya, pendidikan berbasis teknologi mobile ini dikhawatirkan oleh beberapa pihak karena teknologi mobile dapat memunculkan efek samping negatif bagi siswa. Selain itu, hanya ada sedikit penelitian yang membahas penggunaan teknologi mobile sekolah-sekolah tingkat menengah di Indonesia. Hal-hal tersebut membuat banyak pemangku kepentingan atau stakeholder di Indonesia meragukan penerapan pendidikan berbasis teknologi mobile, termasuk tantangan dalam pelaksanaannya. Oleh karena itu, makalah ini bertujuan untuk memberikan wawasan teoritis dalam upaya penerapan dan integrasi pembelajaran Bahasa Inggris dengan teknologi mobile (atau MALL - mobile-assisted language learning) untuk siswa di tingkat sekolah menengah. Wawasan teoritis atau temuan dari makalah ini tersebut dibangun dari analisis sekunder melalui metode penelitian pustaka berbasis 'systematic review', dengan fokus pada penelitian primer tentang MALL dan EFL, serta dokumen pemerintah yang terkait dengan pelaksanaan pendidikan di tingkat sekolah menengah. Makalah ini menawarkan pendekatan pembelajaran baru berdasarkan teori pembelajaran kolaboratif (collaborative learning) dan pengajaran bahasa berbasis tugas (TBLT - task-based language teaching) untuk pelaksanaan dan integrasi MALL di pembelajaran EFL. Selain itu, makalah ini juga membahas masalah yang berpotensi menghambat implementasi MALL di Indonesia kedepannya, yakni kurangnya kesiapan teknologi dari stakeholder EFL dan masih terbatasnya kemampuan pedagogi guru terkait pendidikan berbasis teknologi mobile. Hasil
\end{abstract}


Celtic: A Journal of Culture, English Language Teaching, Literature and Linguistics

Vol. 7, No. 2, December 2020.

E-ISSN: 2621-9158 P-ISSN:2356-0401

http://ejournal.umm.ac.id/index.php/celtic/index

temuan di makalah ini diharapkan dapat meningkatkan kesadaran akan besarnya peluang pemanfaatan MALL di Indonesia dan membuka potensi penelitian primer terkait penerapan MALL di pembelajaran EFL di Indonesia.

Kata Kunci: EFL; Desain Instruksional Pembelajaran; MALL; Sekolah Tingkat Menengah; $T B L T$

\section{INTRODUCTION}

Mobile learning is gaining popularity in Indonesia, especially in secondary schools. According to the Global Education Census 2018, 67\% of secondary school students in Indonesia use smartphones in the classrooms, and 81 percent of students use smartphones to finish their homework (Cambridge Assessment International Education, 2018). This situation aligns with the Indonesian Ministry of Education and Culture (MEC) program about mobile learning initiatives. MEC initiated a mobile learning program in 2012 through a division called Balai Pengembangan Multimedia (BPM), and BPM is responsible for developing mobile learning applications for K-12 students (BPMPK, 2016, 2017).

However, the rise of mobile learning has been challenged by the negative perspective on the misuse of mobile devices and the internet by students. For instance, the former Indonesian Ministry of Woman Empowerment and Child Protection, Yohana S. Yembise, was eager to ban smartphones from all K-12 schools in 2016 to protect students from harmful content from the internet (Dzakwan, 2016). Even though the plan was never implemented fully, such a negative perspective towards mobile learning also happens in many places across the country. In 2019, a district in East Java warned the teachers not to play with their smartphones in the classrooms (Arista, 2019). Some religion-based senior high schools have also prohibited their students from bringing smartphones to schools for years (Asdi, 2018). Those cases suggest that smartphones provide students with access to unimportant and harmful content on the internet, such as social media and pornography. Thus, keeping away smartphones from students is considered a positive attempt to ensure students' safety during teaching and learning activities.

Despite those concerns, many international experts and studies have suggested that mobile devices can be highly beneficial for students' learning activities, especially in language learning like English as a foreign language (EFL). Mobile devices are argued to replace personal computers and give more affordable, intuitive, and innovative language learning platform (Sharpies, Taylor, \& Vavoula, as cited in Samaie, Mansouri, \& Qaracholloo, 2016, p. 1). Moreover, based on my anecdotal experiences as an EFL teacher and a digital learning practitioner, mobile devices could provide broader learning accesses, and opportunities for underprivileged learners as smartphones are getting more and more affordable. On the other hand, a series of reviews on Google Scholar publications between 2016 and 2020 indicates that only a few papers discuss the integration of mobile technologies in EFL classrooms in Indonesian secondary schools, especially in terms of instructional designs. Many of these studies focus only on the implementation of mobile learning in higher education level and science-related subjects. Therefore, this paper aims to explore the utilisations and integrations of mobile learning in EFL classrooms, or mobile-assisted language learning (MALL), to improve the learning experiences of secondary school students in Indonesia. Since there are 
Biantoro, B. (2020). Exploring The Integrations of MALL into English Teaching and Learning for Indonesian EFL Students in Secondary Schools. Celtic: A Journal of Culture, English Language Teaching, Literature and Linguistics, 7(2), 102-117.

many kinds of mobile technologies, this paper focuses only on smartphones and mobile applications for MALL.

\section{The Nature of MALL}

Learning using mobile devices is different from learning using a personal computer or a laptop, known as computer-assisted language learning (CALL). The affordance of mobility and the internet can introduce more possibilities in improving language learning. For instance, students may learn English reading skills by reading online news in their commutes to schools through their smartphones. This stayconnected feature is difficult to achieve using personal computer and laptops, and further differentiate CALL and MALL. As a result, it is essential to define MALL properly. In this paper, mobile-assisted language learning or MALL can be defined as any utilization of mobile devices along with wireless technology for improving the quality and authenticity of language learning activities, in which it also offers flexibility for the students and is unrestrained by time and place (Hashemi, Azhizinezhad, Najafi, and Nesari, 2011; Burston, 2014; Churchill, Fox, and King, 2012). The utilization of mobile devices has just reached the optimum point for learning nowadays as the Web 2.0 era has emerged. Many technologies are emerging for mobile devices, such as mobile applications (apps), advanced wireless fidelity (WIFI) and mobile carrier internet technology, high-resolution touchscreen display, video cameras, and large data storage. Among those features, mobile applications have emerged as MALL's main representative (Burston, 2014). There are four particular characteristics of mobile devices based on applications that are important for language learning (Sung, Chang, \& Yang, 2015):

\section{Mobility and portability}

Despite the smaller size, mobile devices can help students access the internet and practice language in real-time easily through their applications. For example, using a smartphone application such as Google Translate, students can translate signs or announcements written in English in real-time by using their smartphone camera, which is integrated with the application.

\section{Social connectivity/interaction}

Social media applications like Facebook and WhatsApp provide a social platform where students can work collaboratively. For example, WhatsApp is an essential social application to share learning instructions and content with students and colleagues. One benefit of using WhatsApp is that it works without interferences in advertisements or unwanted content like other social media. Thus, it can add an extra layer of protection for students from harmful contents during learning activities.

\section{Context sensitivity}

GPS (Global Positioning System) technology is embedded in almost all current smartphones and tablets, even the cheapest ones. GPS can 'contextualize' searching features and apps to provide more appropriate learning resources for language learning. For instance, the Google Chrome browser application often asks for location information to further refine searches for more contextual search results. If students or teachers want to get online magazines written in English, they might get some results 
Celtic: A Journal of Culture, English Language Teaching, Literature and Linguistics

Vol. 7, No. 2, December 2020.

E-ISSN: 2621-9158 P-ISSN:2356-0401

http://ejournal.umm.ac.id/index.php/celtic/index

from Indonesian websites instead of overseas websites. In this case, contextual materials are expected to help students study English more familiarly and safely.

\section{Individuality}

One of the best perks of having mobile devices for learning is the ability to adjust to learners' aptitude, needs, and learning growth. It is beneficial for students who want to improve their ability outside classrooms. For instance, by using English learning apps like "DuoLingo", students can choose what kind of materials they want to learn first based on their current ability or aptitude. This characteristic is also helpful for students with disabilities who may experience restrictions in accessing some learning activities (Hashemi et al., 2011).

Those four characteristics enable mobile devices to create situational, interactive, contextual, and personalized English learning crucial for EFL (English as Foreign Language) students in Indonesia. Besides, there is one more beneficial characteristic of mobile language devices, namely enjoyment. Many language-learning mobile applications have incorporated game-element to promote joyful and challenging experiences, such as Duolingo: Learn Languages Free, Learn Languages: Rosetta Stone, and Memrise: Learn a new language. Gamification of learning in mobile language learning applications is suggested to increase students' interest, motivation, and satisfaction (Chang, Liang, Chou, \& Lin, 2017).

Moreover, smartphones are chosen as the primary mobile technology for MALL discussed in this paper because they are suggested to promote more communicative capability than other mobile devices in language learning (Leis, Tohei, \& Cooke, 2015). Also, they are on track to be the most popular mobile devices in Indonesia. According to the Indonesian Internet Service Provider Association (APJII) in 2016, 132.7 million Indonesians have connected to the Internet, and 70 percent of internet users reported used mobile devices to access the internet (Indotelko, 2016). Interestingly, more than one-third of Indonesian people connected to the internet are youth, ranging from 15-24 years old. That range of age belongs to junior high schools until undergraduate students (Suhardi, 2016). Based on the data, it is implied that many secondary students in Indonesia are familiar enough with the internet and mobile devices to enable MALL in English education.

\section{Teaching MALL for EFL Students in Indonesia}

Even though mobile devices can promote good learning, they possess some disadvantages to the learning process, such as access to inappropriate content (Sung et al., 2015), creating a double-edged sword effect. Like other internet-based technologies, a smartphone with Internet access may be used by students as a medium to discover their sexual identities (Hall, as cited in Powell, 2010). In fact, the expansion of technology is often associated with pornographic content distribution (Barron \& Kimmel, 2000). A study conducted for secondary students in Nigeria shows easy access to the internet could expose children to offensive materials like pornography (Olatokun, 2008). Hence, Ally (2013) argues that people should concern about the distractions and non-academic activities enabled by mobile devices. Meanwhile, he also suggests that mobile learning becomes a new direction in many educational institutions, including Indonesia. A study conducted in Indonesian higher education in 2015 concludes that 
Biantoro, B. (2020). Exploring The Integrations of MALL into English Teaching and Learning for Indonesian EFL Students in Secondary Schools. Celtic: A Journal of Culture, English Language Teaching, Literature and Linguistics, 7(2), 102-117.

students are ready to incorporate mobile learning in their learning process, and there is a high availability of private access to learning devices, especially mobile devices (38 percent) (Paturusi, Chisaki, Usagawa, \& Lumenta, 2015). Similarly, based on a study in 2014, Indonesian secondary school teachers are reported to see mobile learning as an essential new method of learning that needs to be integrated into face-to-face learning (Yusri, Goodwin, \& Money, 2015). The study shows that teachers' positive knowledge and readiness in MALL of English subject were already more than 50 percent, and more than 90 percent of English teachers were reported to have suitable mobile devices for MALL.

Unfortunately, teaching EFL to Indonesian students has been problematic. A study by Anwar and Arifani (2016) explains that Indonesian English teachers have problems in adopting and implementing teaching strategies and materials for local settings that work well in developed countries, even though suitable English materials have been developed in Indonesia for years. On the other hand, the study has identified that Indonesian EFL students are interested in using contextual, technology-based instructional, and multimedia materials incorporated into the English curriculum. It is possible that the integration of technology can improve the quality of English teaching strategies and materials. Even though the study is conducted based on investigating the integration of computer-assisted language learning (CALL), mobile devices nowadays have sufficient abilities to replace computers in language learning, as suggested in the prior discussion.

Furthermore, the implementation of MALL in English education supports the teaching strategies emerging in Indonesian classrooms. For example, collaborative taskbased language teaching (TBLT) can be beneficial with MALL integration (Anwar \& Arifani, 2016; Burston, 2014). TBLT can be defined as a learning approach focusing on enhancing social communication interaction to master the target language through a series of goal-oriented, meaningful, and communicative learning activities (Hismanoglu \& Hismanoglu, 2011). TBLT is suitable for Indonesia's English curriculum content, which focuses on scientific, project-based, interactive, and higher-order thinking skills (HOTS) learning (Ansori, 2019). TBLT is also mentioned to positively connect with technology-assisted learning for EFL students in Japan (Thomas, as cited in Anwar \& Arifani, 2016). Therefore, it is assumed that using a collaborative TBLT approach is suitable in exploring the strategies to implement MALL for Indonesian EFL students.

\section{METHOD}

The paper is presented as a theoretical research or literature review paper and developed using a systematic review to answer the review questions. The systematic review was implemented as this methodology can help researchers understand 'large bodies of information' and answer specific questions in contributing to the existing knowledge of known areas that still need more scientific summaries or evidence (Petticrew \& Roberts, 2006). However, considering the small-scale of this paper, a simplified version of the systematic review was employed with a total of four steps, namely defining the review questions, preparing brief guidance for the literature search (i.e., selecting keywords and journal databases), implementing literature search, and extracting and synthesizing data from primary or secondary studies for findings' 
Celtic: A Journal of Culture, English Language Teaching, Literature and Linguistics

Vol. 7, No. 2, December 2020.

E-ISSN: 2621-9158 P-ISSN:2356-0401

http://ejournal.umm.ac.id/index.php/celtic/index

dissemination. The simplification of the methodology will also be acknowledged as the limitation of this paper.

Moreover, there are two review questions, which become the basis of this paper. The first question is how mobile devices can be utilized for MALL in secondary school EFL classrooms. The second is what possible challenges that may hinder the implementation of MALL in those settings. To answer the questions, several keywords were set to manage and limit the literature search, such as English education for secondary schools and Indonesian contexts, instructional designs, and approaches for the MALL, MALL strategies in EFL. Next, thorough readings and examinations for the literature search are conducted on secondary data consisting of relevant published peerreviewed journals, mainly between 2015 to late 2019, from major online databases like JSTOR, Science Direct, and ProQuest. The series of extracting and synthesizing data were set to produce pertinent findings with high validity and reliability.

Furthermore, prior to disseminating the findings, an explanation of the nature of MALL in language learning and some concerning factors in the implementation of MALL in Indonesia are elaborated to provide a relevant literature review regarding the key aspect and context in this paper. The paper then presents the findings and the discussions of the integration of MALL for EFL and the possible challenges. The conclusion covers further suggestions for secondary school EFL teachers in utilizing mobile devices in the whole-school learning approach.

\section{FINDINGS AND DISCUSSION}

\section{A. Integrating MALL into EFL Classrooms}

Mobile device integration in Indonesian classrooms is lower than personal computers (Paturusi et al., 2015). It explains why half of the Indonesian teachers are unfamiliar with what mobile learning is about, including classroom utilization (Yusri et al., 2015). Meanwhile, Yusri et al. (2015) study that Indonesian teachers think mobile learning will be beneficial for learning. They intend to learn more about mobile learning practices, including in English subject. Looking at a similar case in Iran, one of the developing countries starting to use MALL, Iranian EFL students are suggested to obtain ubiquitous learning opportunities by utilizing mobile learning, even without teachers' intervention (Dashtestani, 2016). Nevertheless, teachers' interventions are needed to get a positive language learning effect by integrating suitable key features in the learning process inside and outside the classrooms (Sung et al., 2015). The interventions can be constructed in the form of teaching strategies that can increase or decrease MALL experiences to suit the curriculum. In most literature, the problem is that the integration of mobile devices in learning is portrayed as overlapping with other technology-based teaching strategies (Alhinty, 2015). Thus, to provide Indonesian teachers with a clear overview of proper smartphone integrations in MALL, we present five categories of MALL implementations for EFL students in Indonesia based on a collaborative TBLT approach adapted from Alhinty (2015):

\section{Communicative integration}

According to Alhinty (2015), mobile devices' most prominent integration in language learning is for communicative purposes. Initially, Churchill, Fox, and King 
Biantoro, B. (2020). Exploring The Integrations of MALL into English Teaching and Learning for Indonesian EFL Students in Secondary Schools. Celtic: A Journal of Culture, English Language Teaching, Literature and Linguistics, 7(2), 102-117.

(2012) proposed mobile application integrations for learning in some categories like communication tools (e.g., WhatsApp, Twitter, and Instagram) and blogging tools (e.g., Blogger, Tumblr, Wordpress.com, and Squarespace). However, in this case, the two prior categories are merged to create a new category that serves as a complete communicative platform for collaborative language learning. For example, Blogger and WordPress used to be a place for authors to post their writings only, but now students can utilize those blogging platforms like social media to exchange ideas and opinions in the comment sections. Indeed, the comment section, which also exists in all social media applications, has helped students communicate with teachers and other students, exchange experiences, and meet 'virtually' to engage in a more natural language learning environment (Alhinty, 2015).

Furthermore, freedom in choosing content to use on social media platforms can initiate various learning activities covering different language skills. In the past, Skype became the main tool to practice direct listening and speaking practices using the video calling feature (Alhinty, 2015). Meanwhile, today's social media applications are competing to put more features on their platform. For example, WhatsApp and Telegram were simple chatting applications, but currently, they have video calling, sharing documents, and audio recording features. In fact, chatting applications like LINE can be used as a learning platform for English spelling on mobile devices (Shih, Lee, \& Cheng, 2014). Therefore, teachers can conduct various learning activities that cover reading, listening, speaking, and writing skills in the classroom just by using smartphones and social media applications. Students can also be encouraged to further use social media applications for MALL outside classrooms, in which the learning process may be turned into blended learning like a flipped classroom.

Nevertheless, teachers have to be aware of the double-edged effects of social media in the classroom. For example, social media are often considered a distraction during learning activities, as Smith (2016) suggested. She also explains that teachers are advised to separate social media's academic and social purposes from overcoming such a problem. For example, teachers can ask students to make different groups or online accounts for academic purposes in their social media applications instead of using their primary accounts. By doing so, students can avoid distractions like unrelated social media notifications and focus more on the learning contents shared by friends, the teacher, or other educational sources that they are following.

\section{Content access integration}

One of the best affordances of having smartphones for MALL is easy access to learning materials and tools. A study conducted by Fojtik (2014) shows that higher education students often utilize mobile applications to access universities' learning materials. Similarly, many Indonesian secondary school students are trying to do the same as the number of smartphone ownerships increasing each year (Cambridge Assessment International Education, 2018). Various types of learning materials and tools have been explored by students digitally. The most popular materials for MALL are probably electronic books (e-book), dictionaries, and multimedia apps (Alhinty, 2015), while web-based dictionaries may be the most common learning tools used by Indonesian students. Additionally, students can easily browse the internet and visit various websites for more learning support nowadays. 
Celtic: A Journal of Culture, English Language Teaching, Literature and Linguistics

Vol. 7, No. 2, December 2020.

E-ISSN: 2621-9158 P-ISSN:2356-0401

http://ejournal.umm.ac.id/index.php/celtic/index

Teachers can exploit digital learning materials by creating continuous and collaborative learning activities using MALL. For instance, in reading skills, teachers can encourage students to download and read more reading materials like light novels, graphic books, comic books, including textbooks in the form of an e-book for extensive reading practices remotely or outside the classrooms. There are many 'free-charge' ebook readers in Android, iOS, and Windows platforms such as Adobe Acrobat Reader, WPS Office, and Polaris office. Interestingly, many e-book applications offer personalized reading experiences by introducing students to more interesting reading materials according to their interests, such as Amazon Kindle, Apple Books, Google Play Books, and eReader Prestigio: Book Reader. Since the e-books are displayed on mobile devices, other activities to enrich the reading practices can be done simultaneously, such as audio recording, highlighting important words, and translating directly from the touchscreen display (Hutchison et al., as cited in Alhinty, 2015). Also, many applications combine e-book with an audiobook like Audible, Google Play Books, and LibriVox Audio Books. They offer a big library of free audiobooks to stream or download along with the e-books version. Students can benefit from those apps by downloading both the e-book and audiobooks to practice their reading and listening skills simultaneously. Many e-books and learning websites also have a 'share' button that enables students to share their favorite learning materials on their social media. By asking students to share their favorite learning materials and their learning progress regularly, teachers may indirectly trigger the possibility of natural collaborative learning among students. In this case, students can easily access and learn from each other's preferred learning materials while being kept motivated by other students' progress.

In addition, according to anecdotal evidence of the writer as an English teacher for secondary and undergraduate students, most Indonesian students who have access to mobile devices rarely use 'book' dictionaries as their learning tool. They prefer to use web-based online dictionaries such as Google Translate on their smartphones since they are easier to use and have rich features. Similar to dictionary software on the computers, most mobile dictionaries like "Merriam-Webster" apps have a quick search feature, and they can display not only definitions of the words but also audio on how to spell the words, pop-up thesaurus, and sharing tools to post selected vocabularies to social media. With the affordance of digital technology such as big build-in data storage and machine learning, web-based dictionaries are better than ever for personal and authentic learning. For example, Google Translate can do offline translations (without the internet), short message service (SMS) translation, and instant text translation using a smartphone's camera. It also has a big database that can translate English words into traditional Indonesian languages like Javanese to better understand students coming from remote areas. Indeed, dictionary application utilization to support EFL learning is important, inside and outside classrooms (Alhinty, 2015).

Moreover, smartphones may give students access to more interactive learning materials like multimedia content that can support authentic language learning. For example, in Indonesian secondary schools, it is popular to use video streaming platforms like YouTube, TikTok, or Instagram to facilitate authentic speaking and listening experiences. Alhinty (2015) emphasizes that young students' interest in learning can be sparked significantly using YouTube videos that contain sound, text, and images. Therefore, teachers can facilitate individual or collaborative meaningful 
Biantoro, B. (2020). Exploring The Integrations of MALL into English Teaching and Learning for Indonesian EFL Students in Secondary Schools. Celtic: A Journal of Culture, English Language Teaching, Literature and Linguistics, 7(2), 102-117.

and authentic tasks that focus on online multimedia contents through popular video streaming platforms for English learning considering its easy access, a wide variety of learning contents, and high relevance to the students' interests.

\section{Productivity integration}

Multitasking and fast content creations are often portrayed as the best benefits of using mobile devices, such as typing and taking notes digitally. In the opposite view, Wollscheid, Sjaastad, and Tømte (2016) suggest that there is no significant evidence to support the existence of benefits in replacing students' handwriting with digital writing in early writing instructions. It is indeed a concerning factor in implementing MALL, mainly when many EFL students in Indonesia are still in the early writing skill stage. However, mobile devices like tablets and smartphones indeed support many applications that help students take notes and draw using fingers or a stylus (Alhinty, 2015). It can be beneficial to improve efficiency, creativity, and supports in EFL learning. Commonly, note-taking applications are bundled in smartphones, even in cheap smartphones. There is also a complete version of note-taking applications like Evernote and Google Keep Notes that enables users to embed pictures, clip web articles, scan pictures, and collaborate on a note-taking project with friends. More importantly, note-taking applications are considered a tool for students' information acquisition and management (Schepman, Rodway, Beattle, \& Lambert, 2012). Some note-taking applications also promote learning affordances to students with disabilities. For instance, Speechnotes, Google Assistant, and Dragon Dictation enable students to make a note from their speech and replay it again in the form of audio. Teachers can explore those affordances in note-taking to offer more creative, collaborative, and supportive EFL learning tasks, even during remote online classes.

Other content creation opportunities can be supported by mobile devices to innovate EFL language learning. Mouzaa and Barrett-Greenly's (2015) study shows that students use productivity applications to create content representations of their literacy in various forms. Based on the writer's colleagues' anecdotal evidence in secondary schools in Malang, Indonesia, many students are introduced to video production for English speaking tasks. For instance, students are instructed to make a short video collaboratively using their smartphones and mobile video editing applications like Viva Video (Android) and iMovie (iOS) before uploading it to YouTube. This implementation can be applied to English story-telling and daily conversation practices instructed in the Indonesian curriculums for secondary schools. This is in-line with Alhinty's idea (2015) where students can practice their new language in and outside the classroom using many productivity methods, e.g., presentations, audio recordings, and photo-capturing activities to represent their language learning through mobile devices. The use of popular content creation platforms and applications can also further improve independent learning activities like peer assessment. For example, students can review and assess other students' videos posted on YouTube or Instagram by posting 'My Response Videos', which are quite popular to do on YouTube. Wenny and Fajar (2019) suggest that peer assessment can be more beneficial for students than regular lectures, especially for EFL communicative skills. Hence, the opportunities promoted by productive applications can be seized by teachers to initiate MALL in the form of 
Celtic: A Journal of Culture, English Language Teaching, Literature and Linguistics

Vol. 7, No. 2, December 2020.

E-ISSN: 2621-9158 P-ISSN:2356-0401

http://ejournal.umm.ac.id/index.php/celtic/index

authentic individual or group projects or other authentic TBLT activities to improve students' EFL learning and interactions in the traditional or online classes.

\section{Interactive integration}

Anwar and Arifani (2016) explain that teaching English in Indonesia has less creativity and contextuality because it is taught similarly to teaching native learners. It implies that there are few efforts in improving the English teaching and learning for EFL students, especially adjusting EFL learning with local content. To address that problem, Patten, Sánchez, and Tangney (2006) propose interactive integration to solve the traditional learning method. In this case, the interactive integration can be defined as a 'drill and test' approach using mobile devices to improve traditional and well-known learning activities using available technology such as by doing simple multiple-choice questions in the digital platform (Patten et al., 2016). Therefore, it is different than communicative integrations previously mentioned.

Alhinty (2015) states that many developers promote 'traditional' educational activities using interactive learning mobile applications and games. "DuoLingo: Learning Language Free" is one example of interactive applications used globally by EFL students. DuoLingo offers many learning activities based on multiple-choice questions (MCQ) and free-form response questions (e.g., fill-in-the-blank questions). Even though some of the contents are not highly contextual for Indonesian students, DuoLingo accommodates learners with a learning section called 'Club'. Students can exchange knowledge or information and learn collaboratively in the Club. DuoLingo also uses a gamification approach in which the traditional language tests are presented like a game where some learners can compete to get the best score. Indeed, such learning tasks often cannot be achieved using traditional drilling techniques in the classroom, but the tasks can be more suitable for 'digital-native' learners by improving their interactivity using digital technology. Moreover, the 'Club' section in DuoLingo enables teachers to deliver instructions and additional feedbacks to keep the students learning on track, even for remote activity.

Furthermore, educational websites like Kahoot and Quizizz provide teachers with a platform to create online digital-based tests. Teachers can easily make and share many multiple-choice tests for EFL skills on those platforms. Students will only need a test link to join the test. It is possible to add pictures, video, and audio in both platforms and set the test for homework for blended learning activities or small classes. Thus, teachers can implement English tests easier while promoting more interactive and contextual assessments.

\section{Storing integration}

Current smartphones can save a large amount of data with the help of additional memory cards or cloud storage, and that storage can be accessed easily by students to keep essential learning materials. Schepman et al. (2012) advise teachers to tell their students to save and back up essential learning data in the cloud services to preserve it in an emergency. Indeed, cloud-based mobile learning can offer portable spaces to back up data to minimalize damage to data loss during learning activities.

Moreover, for educational purposes, cloud-based mobile learning is believed to have new positive impacts in developing innovative learning tasks and improve 
Biantoro, B. (2020). Exploring The Integrations of MALL into English Teaching and Learning for Indonesian EFL Students in Secondary Schools. Celtic: A Journal of Culture, English Language Teaching, Literature and Linguistics, 7(2), 102-117.

students' creativity in EFL learning (Chang, Chien, Yu, Lin, \& Chen, 2016). DropBox, Google Drive, Microsoft OneDrive, and Apple iCloud are popular for educational purposes. Those cloud-based storing applications can be used to save many kinds of learning materials such as English textbooks, videos, and pictures and share the materials with peers and teachers. For example, anecdotal evidence shows that the English teachers in several secondary schools and universities in Malang, East Java, Indonesia, often encourage students to use Google Drive or Google Mail to store assignments with open access so that other students could provide feedback to each other. A study conducted by Chang et al. (2016) concludes that cloud-based mobile learning can promote challenging and motivation-rich environments involving the teachers. It can generate a positive impact on task creation due to its affordance. Therefore, teachers can encourage students to utilize online storage platform to facilitate more transparent, collaborative, and communicative EFL tasks for blended or remote learning.

\section{B. Challenges of Implementing MALL in Indonesian Settings}

Despite the positive features, some potential challenges should be considered in implementing MALL for Indonesian EFL students, namely technology readiness and pedagogical issues constraining teachers and students involved in MALL (Burston, 2014; Kim \& Jang, 2015). First, even though mobile learning is more affordable than learning using a personal computer (PC) or laptops, the initial implementation of oneto-one mobile learning is financially difficult (Burston, 2014; Dashtestani, 2016). For example, based on anecdotal evidence from a small interview with three of the writer's fellow English teachers in Malang, East Java, Indonesia, only high ranking private junior or high schools that try to implement one-to-one MALL by requiring their students to have mobile devices such as tablets and smartphones. Those schools are indeed well-known to have students with high-income parents. A similar case also happened in Iranian EFL students, where many students think that starting mobile learning is expensive even though most of them already own smartphones (Dashtestani, 2016). In a proper MALL implementation, funding support is essential to get suitable hardware and software, including internet access (Burston, 2014). Unlike secondary schools, another anecdotal evidence shows that many higher education institutions in Indonesia provide better hardware and software supports for the students. For example, some universities in Indonesia give new students mobile devices for free when they enroll, such as Malangkucecwara School of Economics in East Java, Indonesia. Universitas Muhammadiyah Malang (UMM), also based in East Java, also provides students with in-house online learning platforms like LMS (learning management system). Indeed, the technology readiness for MALL in Indonesian secondary schools is less desirable than higher education institutions. This situation needs to be taken into consideration by EFL stakeholders while implementing MALL to avoid any shortcomings. Unfortunately, based on Yusri et al.'s (2015) study, most Indonesian teachers are not affected by the financial issue in engaging with mobile learning, including English, since they are reported to be financially independent and capable of affording it. Therefore, technology readiness challenges may affect schools and students more, especially concerning funding for preparing the proper MALL's hardware and software. 
Celtic: A Journal of Culture, English Language Teaching, Literature and Linguistics

Vol. 7, No. 2, December 2020.

E-ISSN: 2621-9158 P-ISSN:2356-0401

http://ejournal.umm.ac.id/index.php/celtic/index

Furthermore, pedagogical issues pose significant barriers to MALL implementation (Burston, 2014; Manca \& Ranieri, 2016). In line with content delivery problems suggested by Burston (2014), many Indonesian teachers are still unfamiliar with mobile learning. They need more training to implement mobile learning in the classrooms (Yusri et al., 2015). If the teachers have poor digital literacy towards mobile learning, MALL's delivery and instructions may not have the intended positive impact. Importantly, teachers hold an important role in guiding the students in using mobile devices for learning and choosing suitable mobile devices and suitable mobile applications (Dashtestani, 2016). To get the most suitable applications or platforms for MALL, teachers need to do research that requires digital expertise. For example, in Indonesia, where most of the students utilize Android-based cheap smartphones, using a Gmail account for email and cloud storage is more recommended instead of a Yahoo or Microsoft Outlook account due to its integration affordances with their devices. Moreover, students' and educational institutions' acceptance of MALL in mobile learning, in general, is concerning. The awakening of mobile learning is perceived as a weakening factor of traditional teachers' and students' roles, and some also consider social media for learning tools as a useless effort (Manca \& Ranieri, 2016). Smith's (2016) study also found out that five problems are surfacing from the students related to social media in learning, namely distraction, a different learning method, lack of credibility, privacy concern, and low familiarity with the social media. That idea corresponds with Dashtestani's (2016) argument stating that educational contents do not meet EFL students' expectations of mobile learning in most developing countries. As a result, many Indonesian schools restrict the use of smartphones for students, for instance, students have to turn off their smartphones during the teaching and learning process to avoid distractions. Fortunately, there is a good perception of mobile learning among Indonesian teachers. Even though many might not be familiar with mobile devices, they view mobile learning as an essential tool for future education and have a high interest in learning them for better implementation (Yusri et al., 2015).

\section{CONCLUSION}

To sum up, the paper has presented possible integrations of MALL in EFL students in Indonesian secondary schools. The MALL's integrations' objectives are to facilitate a more affordable, contextual, continuous, and supportive EFL, both for individual and collaborative learning activities. The paper shows that the preferable MALL implementations in EFL's instructional design covers communicative, content access, productivity, interactive, and storing integrations based on Alhinty's (2015) and TBLT approaches. These integrations are expected to promote more learning opportunities despite the challenges such as lack of theory and teaching strategies in MALL (Burston, 2014).

Furthermore, the paper also highlights the possible challenges plaguing the implementation of the MALL in EFL classrooms. The technology readiness of the schools and students and pedagogical issues of EFL teachers are projected to hinder the implementation of MALL in the secondary schools. Even though such problems may be typical during the initial implementation of MALL, proper immediate supports are needed to improve the future. It is also suggested that EFL teachers spend more time familiarizing themselves with mobile devices since MALL cannot be integrated easily 
Biantoro, B. (2020). Exploring The Integrations of MALL into English Teaching and Learning for Indonesian EFL Students in Secondary Schools. Celtic: A Journal of Culture, English Language Teaching, Literature and Linguistics, 7(2), 102-117.

without teachers' sufficient knowledge and skills (Mouzaa \& Barrett-Greenly, 2015). Teachers are expected to be the pioneers in the implementation as they are more likely to be the first EFL stakeholder who is ready for MALL. Therefore, further primary research on other EFL stakeholders' readiness and real-world implementations of MALL in Indonesian secondary schools is necessary to find the weak links to properly improve MALL and maximize its opportunities in the integration with EFL learning in the future.

\section{REFERENCES}

Alhinty, M. (2015). English-Language Learning at their Fingertips: How Can Teachers Use Tablets to Teach EFL Children? International Journal of Mobile and Blended Learning, 7(2), 19+. doi: 10.4018/ijmbl.2015040104

Ally, M. (2013). Mobile learning: From research to practice to impact education. Learning and Teaching in Higher Education: Gulf Perspectives, 10(2), 1-10. Retrieved from http://lthe.zu.ac.ae/index.php/lthehome/article/viewFile/140/62

Ansori, M. (2019). English Teachers' Efficacy in Using Pedagogical Techniques to Promote Higher Order Thinking Skills. CELTIC: A Journal of Culture, English Language Teaching, Literature \& Linguistics, 6(2), 1-13. Retrieved from http://ejournal.umm.ac.id/index.php/celtic/article/view/9860/pdf

Anwar, K., \& Arifani, Y. (2016). Task-based language teaching: Development of CALL. International Education Studies, 9(6), 168-183. Retrieved from https://search-proquestcom.ezproxy.lib.monash.edu.au/docview/1826544961?accountid=12528

Arista (2019, July 29). Dispendikbud Bondowoso segera terbitkan surat edaran larangan guru bermain gawai [Bondowoso Education Board is going to publish circular letter to ban teachers from playing with phones in the classrooms]. RRI. Retrieved from https://rri.co.id/jember/daerah/700117/dispendikbudbondowoso-segera-terbitkan-se-larangan-guru-bermain-gawai

Asdi (2018, July 30). Siswa tidak boleh bawa HP ke sekolah, ini solusinya [Students are not allowed to bring smartphones to school, here is the solution]. Retrieved from https://kalteng.kemenag.go.id/kanwil/cetak/497293/Siswa-Tidak-Boleh-BawaHP-ke-Sekolah-Ini-Solusinya

Balai Pengembangan Multimedia Pendidikan dan Kebudayaan (BPMPK) [Multimedia Development Agency of Indonesian Ministry Education and Culture]. (2016). Virtual Laboratorium [Virtual Laboratory]. Retrieved from http://medukasi.kemdikbud.go.id/medukasi/?m1=vlab\&kd=ME16VLAB01

Balai Pengembangan Multimedia Pendidikan dan Kebudayaan (BPMPK) [Multimedia Development Agency of Indonesian Ministry Education and Culture]. (2017). Sejarah BPMPK [History of BPMPK]. Retrieved from http://medukasi.kemdikbud.go.id/medukasi/?m1=sejarah

Barron, M., \& Kimmel, M. (2000). Sexual Violence in Three Pornographic Media: Toward a Sociological Explanation. The Journal of Sex Research, 37(2), 161$168 . \quad$ Retrieved from http://www.jstor.org.ezproxy.lib.monash.edu.au/stable/3813601

Burston, J. (2014). MALL: The pedagogical challenges. Computer Assisted Language Learning, 27(4), 344-357. doi: 10.1080/09588221.2014.914539 
Celtic: A Journal of Culture, English Language Teaching, Literature and Linguistics

Vol. 7, No. 2, December 2020.

E-ISSN: 2621-9158 P-ISSN:2356-0401

http://ejournal.umm.ac.id/index.php/celtic/index

Cambridge Assessment International Education. (November, 2018). Indonesian students among the world's highest users of technology. Retrieved from https://www.cambridgeinternational.org/news/news-details/view/indonesianstudents-among-the-worlds-highest-users-of-technology-27-nov2018/

Chang, C.C., Liang, C., Chou, P.N., \& Lin, G.Y. (2017). Is game-based learning better in flow experience and various types of cognitive load than non-game-based learning? Perspective from multimedia and media richness. Computers in Human Behavior, 71, 218-227. doi: 10.1016/j.chb.2017.01.031

Chang, Y.H., Chien, Y.H., Yu, K.C., Lin, H.C., \& Chen, M.Y.C. (2016). Students' innovative environmental perceptions and creative performances in cloud-based m-learning. Computers in Human Behavior, 63, 988-994. doi: 10.1016/j.chb.2016.06.032

Churchill, D., Fox, B., \& King, M. (2012). Study of affordances of iPads and teachers' private theories. International Journal of Information and Education Technology, 2(3), 251+. doi: 10.7763/IJIET.2012.V2.122

Dashtestani, R. (2016). Moving bravely towards mobile learning: Iranian students' use of mobile devices for learning English as a foreign language. Computer Assisted Language Learning, 29(4), 815-832. doi: 10.1080/09588221.2015.1069360

Dzakwan, S. (2016, September 7). Permen Larangan Bawa HP di Sekolah Segera Disahkan [The ministerial decree for banning smartphones from schools will be enacted]. Sindonews. Retrieved from https://daerah.sindonews.com/read/1137359/174/permen-larangan-bawa-hp-disekolah-segera-disahkan-1473220859

Fojtik, R. (2015). Ebooks and Mobile Devices in Education. Procedia - Social and Behavioral Sciences, 182, 742-745. doi: 10.1016/j.sbspro.2015.04.824

Hashemi, M., Azhizinezhad, M., Najafi, V., \& Nesari, A. J. (2011). What is Mobile Learning? Challenges and Capabilities. Procedia - Social and Behavioral Sciences, 30, 2477-2481. doi: 10.1016/j.sbspro.2011.10.483

Hismanoglu, M., \& Hismanoglu, S. (2011). Task-based language teaching: What every EFL teacher should do. Procedia - Social Behavioral Sciences, 15, 46-52. doi: 10.1016/j.sbspro.2011.03.049

Indotelko. (2016, October 25). Ini profil industry internet Indonesia untuk 2016 [Here are the Indonesian Internet industry profiles for 2016]. Retrieved from http://www.indotelko.com/kanal?c=id\&it=profil-industri-internet-indonesia2016

Kim, H.J., \& Jang, H.Y. (2015). Factors influencing students' beliefs about the future in the context of tablet-based interactive classrooms. Computers \& Education, 89, 1-15. doi: 10.1016/j.compedu.2015.08.014

Leis, A., Tohei, A., \& Cooke, S.D. (2015). Smartphone Assisted Language Learning and Autonomy. International Journal of Computer-Assisted Language Learning and Teaching (IJCALLT), 5(3), 75-88. doi:10.4018/IJCALLT.2015070105

Manca, S., \& Ranieri, M. (2016). Facebook and the others. Potentials and obstacles of Social Media for teaching in higher education. Computer \& Education, 95, 216230. doi; 10.1016/j.compedu.2016.01.012 
Biantoro, B. (2020). Exploring The Integrations of MALL into English Teaching and Learning for Indonesian EFL Students in Secondary Schools. Celtic: A Journal of Culture, English Language Teaching, Literature and Linguistics, 7(2), 102-117.

Mouzaa, C., \& Barrett-Greenly, T. (2015). Bridging the app gap: An examination of a professional development initiative on mobile learning in urban schools. Computer \& Education, 88, 1-14. doi: 10.1016/j.compedu.2015.04.009

Olatokun, W.M. (2008). Internet access and usage by secondary school students in a Nigerian Municipality. South African Journal of Libraries and Information Science, $\quad 74(2), \quad 138 \quad-\quad 148 . \quad$ Retrieved from http://journals.co.za.ezproxy.lib.monash.edu.au/content/liasa/74/2/EJC61298

Patten, B., Sánchez, I.A. \& Tangney, B. (2006). Designing collaborative, constructionist and contextual applications for handheld devices. Computers \& Education, 46(3), 294-308. doi: 10.1016/j.compedu.2005.11.011

Paturusi, S., Chisaki, Y., Usagawa, T., \& Lumenta, A. (2015). A study of students' acceptance toward mobile learning in higher education institution in Indonesia. 2015 International Conference on Information \& Communication Technology and Systems (ICTS), Surabaya, 2015, 193-196. doi: 10.1109/ICTS.2015.7379897

Petticrew, M., \& Roberts, H. 2006. Systematic reviews in the social sciences: A practical guide. Blackwell Publishing. doi: 10.1002/9780470754887

Powell, A. (2010). Configuring consent: emerging technologies, unauthorised sexual images and sexual assault. Australian and New Zealand Journal of Criminology, 43(1), 76+. Retrieved from http://go.galegroup.com.ezproxy.lib.monash.edu.au/ps/i.do?p=AONE\&sw=w\&u $=$ monash \&v=2.1\&it=r\&id=GALE\%7CA225580544\&asid=30ab269f6c3b4ef47 7c88f2101c74863

Samaie, M., Mansouri N. A., \& Qaracholloo, M. (2016). An inquiry into the efficiency of WhatsApp for self- and peer-assessments of oral language proficiency. British Journal of Educational Technology. doi:10.1111/bjet.12519

Schepman, A., Rodway, P., Beattle, C., \& Lambert, J. (2012). An observational study of undergraduate students' adoption of (mobile) note-taking software. Computers in Human Behavior, 28(2), 308-317. doi: 10.1016/j.chb.2011.09.014

Shih, R.C., Lee, C., \& Cheng, T.F. (2015). Effects of English Spelling Learning Experience through a Mobile LINE APP for College Students. Procedia Social and Behavioral Sciences, 174, 2634-2638. doi: 10.1016/j.sbspro.2015.01.945

Smith, E. E. (2016). "A real double-edged sword:" Undergraduate perceptions of social media in their learning. Computers \& Education, 103, 44-58. doi: 10.1016/j.compedu.2016.09.009

Suhardi, D. (2016). Indonesia Educational Statistics in Brief 2015/2016: Technical Report. Pusat Data dan Statistik Pendidikan dan Kebudayaan, Jakarta.

Sung, Y. T., Chang, K. E., \& Yang, J. M. (2015). How effective are mobile devices for language learning? A meta-analysis. Educational Research Review, 16, 68-84. doi: 10.1016/j.edurev.2015.09.001

Wenny, S. J., \& Fajar, R. (2019). The effect of peer assessment towards students' speaking skill at semester II of University of Muhammadiyah Jambi. CELTIC: A Journal of Culture, English Language Teaching, Literature \& Linguistics, 6(2), 26-32. Retrieved from http://ejournal.umm.ac.id/index.php/celtic/article/view/9886 
Celtic: A Journal of Culture, English Language Teaching, Literature and Linguistics Vol. 7, No. 2, December 2020.

Wollscheid, S., Sjaastad, J., \& Tømte, C. (2016). The impact of digital devices vs. Pen(cil) and paper on primary school students' writing skills - A research review. Computers \& Education, 95, 19-35. doi: 10.1016/j.compedu.2015.12.001

Yusri, I.K., Goodwin, R., \& Mooney, C. (2015). Teachers and Mobile Learning Perception: Towards a Conceptual Model of Mobile Learning for Training. Procedia - Social and Behavioral Sciences, 176, 425-430. doi: 10.1016/j.sbspro.2015.01.492 